\title{
NECESSITIES VERSUS ETHICAL CONSIDERATIONS - THE REALITIES OF COVID-19 AND THE MORAL STRAIN THEY ENFORCE ON SOCIETY
}

\author{
Martin Mirchev, Albena Kerekovska \\ Department of Social Medicine and Healthcare Organization, Faculty of Public Health, \\ Medical University of Varna
}

\begin{abstract}
INTRODUCTION: After the initially chaotic and sporadic worldwide response to the COVID-19 pandemic, measures and strategies against the spread of this modern-time plague are getting shape and are relatively well adopted. In this environment, we witness the process of hard re-prioritization of needs, re-allocation of resources and some strict means to limit certain freedoms and actions.

On the ethical ground, issues of social justice and individual rights are colliding in the shape of a conflict between infringement of rights and violation of rights. In this humanitarian crisis, we observe yet another confrontation of public against individual interest.

AIM: The aim of this article is to bring up for discussion from an ethical standpoint freedoms and ultimately rights - in light of the current precautionary measures and the way they affect our social interactions.

MATERIALS AND METHODS: Ethical analysis and documental research was conducted, including approved World Health Organization (WHO) statistics and data, experts' reports, action recommendations, guidelines for measures, and standards of care in a pandemic situation.

RESULTS AND CONCLUSION: There are different approaches among people towards the pandemic, hence leading to attitudes spanning from indifference and ignorance, to conspiracy suspicions. Others believe that their rights are being unjustly violated. Even though some government strategies suggest debatable - on ethical grounds measures - we need to reconsider our typical expectations of social justice, priorities, and autonomy. Rights and freedoms need to be flexible in contexts of mass disasters, just like our attitude needs to be. To ensure their application in times of peace and prosperity, we need to be ready to give away some of them in times of crisis/pandemic.
\end{abstract}

Keywords: ethics, rights, justice, priority, pandemic, COVID-19

Address for correspondence:

Martin Mirchev

Faculty of Public Health

Medical University of Varna

55 Marin Drinov St

9002 Varna

e-mail: martin.mirchev@mu-varna.bg

Received: May 6, 2020

Accepted: June 19, 2020

\section{INTRODUCTION}

After the initially chaotic and sporadic worldwide response to the COVID-19 pandemic, measures and strategies against the spread of this modern-time plague are getting shape and are relatively well adopted. In this environment, we witness the process of hard re-prioritization of needs, re-allocation of resources and some strict means to limit certain freedoms and actions. 
On the ethical ground, issues of social justice and individual rights are colliding in the shape of a conflict between infringement of rights and violation of rights. In this humanitarian crisis, we observe yet another confrontation of public against individual interest.

\section{AIM}

The aim of this study is to bring up for discussion from an ethical standpoint freedoms and ultimately rights - in light of the current precautionary measures and the way they affect our social interactions.

\section{MATERIALS AND METHODS}

The methods involve ethical analysis based on the main theories of utilitarianism and biomedical principles of justice and autonomy.

Documental research has been performed on official publications, experts' reports, approved WHO statistics and data, action recommendations, guidelines for measures, and standards of care in pandemic situation.

\section{RESULTS AND DISCUSSION}

In the midst of the COVID-19 crisis, we are still not sure exactly when and how we are going to overcome it. The image of the price we are ultimately going to pay - in human life, resources, economic consequences - on the other hand, is getting brighter and brighter. Not surprisingly, a set of measures were taken around the world with the sole intention of putting a halt on the seemingly uncontrollable and boundless spread of the virus. The measures themselves are not that different, but certain attitudes in light of those measures vastly vary.

One of the terms which gets more and more attention these days is priority. And priority, especially in the context of public healthcare, is a thing that often conflicts with justice and autonomy as fundamental ethical requirements, and eventually affects social justice, as generally understood in terms of fair relations between the individual and society. Issues of social justice arise in circumstances in which people can advance their claims - to freedom, opportunities, resources - that are potentially conflicting, and we appeal to justice to resolve such conflicts by determining what each person is properly entitled to have. In contrast, where people's interests converge, the decision to be taken is about the best way to pursue some common purpose. In that sense, the ethical considerations about autonomous choices, actions and informed decisions, is greatly affected by some of the pandemic measures. Naturally, limitations, infringement/violation of rights and priorities become interdependent.

There is no doubt that, in dire situations like the one we are facing now, setting priorities and dealing with the allocation of scarce resources is way more problematic. It is logical to assume that extreme measures could, are, and will be taken, regardless of whether we are considering certain basic freedom limitations, setting limits on access to treatment, or rationing in terms of age and health condition $(1,2)$. Since humanity proved to be unprepared for a global pandemic, the question is not whether to reshape priorities according to the situation, but to do it consistently and decisively, and in an ethical manner.

Some proposals (3) include maximizing the benefits produced by limited resources, which may suggest saving the most individual lives or saving potentially the most life-years by giving priority to patients likely to survive longest after treatment $(4,5,6,7)$; treating people equally, which in the reality of scarcity, may include random selection (lottery principle), or the first-come, first-served method of distribution $(3,7)$; promoting and rewarding instrumental value by giving priority to those who can save others, or reward by giving priority to those who have saved others in the past $(3,8)$; and giving priority to those, who are worst off, by prioritizing either the sickest, or the younger people who will potentially live the shortest lives if they are untreated $(3,7,8,9)$. Needless to say, the stated mechanisms and proposals, as well as others, already implemented - like the social distancing and isolation, quarantine and labor limitations - provoke ethical considerations in the specter of autonomy, social justice and infringement/ violation of rights. It may sound ironical given the hygiene precautions today, but in philosophy, this is called the problem of "dirty hands" (10).

The "dirty hands" (11) concept in general is related to the concern whether political leaders should violate the deepest constraints of morality and social freedoms in order to achieve great goods or avoid di- 
sasters for their communities. There are many different aspects to the philosophical debate about this topic, and they shed light on many of the complexities in more popular thinking about politics and morality. All, however, involve the idea that correct political action must sometimes conflict with profound moral norms and freedoms. Essentially, this concept suggests that only something like the circumstances of "supreme emergency" (11) could provide a "dirty hands justification.” Michael Walzer says, "...dirty hands aren't permissible (or necessary) when anything less than the on-goingness of the community is at stake, or when the danger that we face is anything less than communal death" (12). One can easily find certain similarities between the "dirty hands" and the utilitarian interpretations. Priority for limited resources should aim both at saving the most lives and at maximizing improvements in individuals' posttreatment length of life - greatest good for the greatest number of people. Saving more lives and more years of life is a consensus point across some expert reports $(5,6,7)$. It is consistent both with utilitarian ethical perspectives that emphasize population outcomes and with non-utilitarian views that emphasize the paramount value of each human life (13). So what about our rights in this pandemic context?

According to Ronald Dworkin, particularly the critical interests of individuals (mainly against state policies) are well protected by rights that have the power of "trump" cards (14). This metaphor for "trumps" is not entirely appropriate for cases where one moral right is confronted with another moral right, as is the case in many practical situations. If the state needs to protect the rights of citizens for example, to prevent the spread of a catastrophic disease - then it may legitimately override individual rights such as the right to refuse vaccinations (or refuse to administer vaccinations, as it is the case now). Dworkin himself gives limited importance to trump rights, saying that rights are best understood as trumps against some background justifications for political decisions that set goals for the whole society (15). So understood, rights are instruments whose function is to ensure that individuals are not sacrificed for government interests or those of the majority, but nevertheless cannot always be absolutely applicable "trumps". This interpretation sounds appealing in some contexts where individuals are vul- nerable to serious harms and in which we identify unfair outcomes stemming from the conflict between collective interest and individual preferences. The reason why rights are special and especially valued is that individuals may have justifiable claims to exercise. Therefore, all rights, like all principles and rules of obligations, are presumptively valid claims that sometimes, however rarely, must be disregarded at the expense of others.

In the light of this need to balance claims, the violation of rights must be clearly distinguished from infringement of rights (16). In the first case, it is an unjustified or erroneous action against an interest protected by a right, while in the second it is an act that may or may not legitimately revoke a right (17). The concept of "rights as justified claims“ - human and/or patient, is always a sensitive topic. Whether we are interpreting certain strategies for limiting the spread of the virus as infringement or violation of rights, we need to have a sober overview of the context. Dealing with the resource shortages and divergence of visions suggests that even ethical considerations vary in times of peace and in times of struggle. Hence, fair allocation and certain limitations require a multi-value ethical framework that can be adapted, depending on the resource and context $(13,18,19,20)$. It seems like no single strategy looks sufficient or good enough to determine who should have access to the limited resources, or should get priority treatment. Essentially, it all comes down to limiting the spread of the virus and lowering the number of people who would need access to the resources. Even when we accept that certain measures, like those literally depriving individuals from usual freedoms, are applied justly, they may still be regarded as morally regrettable. In the clinical environment, the allocation of resources is challenging the ethical considerations and rights in a profound way. The realities of a pandemic might make it justifiable to give priority to maximizing the number of patients who will live through treatment, while their overall quality of life and improvement in terms of length of life is a secondary objective.

\section{CONCLUSION}

These, and many other considerations are challenging our sensitiveness about what is ethically justifiable, and what is not. It is probably better to as- 
sume, that the wrongness or rightness of the different measures enforced by government policies can be subjected to an overall rational and moral evaluation only after the COVID-19 crisis is over. The realities of the pandemic and the necessity for governmental measures and reaction for public interest protection justify reconsideration of our typical expectations of social justice, priorities, and autonomy. Personal rights and freedoms need to be flexible in the context of mass disasters, just like our attitude needs to be. To ensure their application in times of peace and prosperity, we need to be ready to give away some of them in times of crisis, such as the current pandemic.

As of 20.04.2020, according to WHO, (21) there are 2314621 confirmed cases, 157847 confirmed deaths, 212 countries, areas or territories with cases. Yes, numbers are way behind the last truly devastating pandemic - the Spanish flu of 1918-1920, estimated to have affected around 500000000 (quarter of the world population by that time), resulting in anywhere between 17 to 50000000 deaths. (22).

But we don't have to wait to get the current numbers that high, in order to comprehend the profound need for practical and ethical compromises, do we?

\section{REFERENCES}

1. Riccioni L, Bertolini G, Giannini A, Vergano M, Gristina G, Livigni S, et al. Clinical ethics recommendations for the allocation of intensive care treatments, in exceptional, resource-limited circumstances. Italian Society of Anesthesia, Analgesia, Resuscitation, and Intensive Care (SIAARTI). Recenti Prog Med. 2020;111(4):20711. Italian. doi: 10.1701/3347.33183. Available from: http://www.siaarti.it/SiteAssets/News/ COVID19\%20\%20documenti\%20SIAARTI/ SIAARTI\%20-\%20Covid-19\%20\%20Clinical\%20 Ethics\%20Reccomendations.pdf.

2. Mounk Y. The extraordinary decisions facing Italian doctors. Atlantic. March 11, 2020 Available from: https://www.theatlantic.com/ideas/ archive/2020/03/who-gets-hospital-bed/607807/.

3. Emanuel EJ, Persad G, Upshur R, Thome B, Parker M, Glickman A, et al. Fair allocation of scarce medical resources in the time of Covid-19. N Engl J Med. 2020;382(21):2049-55. doi: 10.1056/ NEJMsb2005114.
4. Persad G, Wertheimer A, Emanuel EJ. Principles for allocation of scarce medical interventions. Lancet. 2009; 373(9661):423-31. doi: 10.1016/ S0140-6736(09)60137-9.

5. Emanuel EJ, Wertheimer A. Public health: who should get influenza vaccine when not all can? Science. 2006; 312 (5775):854-5. doi: 10.1126/ science. 1125347 .

6. Biddison LD, Berkowitz KA, Courtney B, De Jong CM, Devereaux AV, Kissoon N, et al. Ethical considerations: care of the critically ill and injured during pandemics and disasters: CHEST consensus statement. Chest. 2014; 146(4 Suppl):e145S-55S. doi: 10.1378/chest.14-0742.

7. Interim updated planning guidance on allocating and targeting pandemic influenza vaccine during an influenza pandemic. Atlanta: Centers for Disease Control and Prevention, 2018. Available from: https://www.cdc.gov/flu/pandemicresources/national-strategy/planning-guidance/ index.html.

8. Rosenbaum SJ, Bayer R, Bernheim RG, et al. Ethical considerations for decision making regarding allocation of mechanical ventilators during a severe influenza pandemic or other public health emergency. Atlanta: Centers for Disease Control and Prevention, 2011. Available from: https://www.cdc.gov/od/science/integrity/phethics/ docs/Vent_Document_Final_Version.pdf.

9. Zucker H, Adler K, Berens D, et al. Ventilator allocation guidelines. Albany: New York State Department of Health Task Force on Life and the Law, November 2015. Available from: https://www. health.ny.gov/regulations/task_force/reports_ publications/docs/ventilator_guidelines.pdf.

10. Christian MD, Sprung CL, King MA, Dichter JR, Kissoon N, Devereaux A, et al. Triage: care of the critically ill and injured during pandemics and disasters: CHEST consensus statement. Chest. 2014; 146(4 Suppl):e61S-74S. doi: 10.1378/ chest.14-0736.

11. Walzer M. The problem of dirty hands. Philos Public Aff. 1973; 2(2):160-80. Available from: https://www.sss.ias.edu/files/pdfs/Walzer/Politicalaction.pdf.

12. Walzer M. Emergency Ethics. In: Walzer M. Arguing About War. New Haven:Yale University Press; 2003. pp. 33-50. 
13. Kerstein SJ. Dignity, disability, and lifespan. J Appl Philos. 2017;34(5):635-50. doi:10.1111/japp.12158.

14. Dworkin R. Taking rights seriously. Cambridge, MA: Harvard University Press; 1977. Available from: https://scholarship.law.edu/cgi/viewcontent. cgi? article $=2438 \&$ context $=$ lawreview .

15. Dworkin R. Rights as trumps. In: Waldron J, editor. Theories of rights. Oxford: Oxford University Press; 1984. p.153. Available from: http://fs2. american.edu/dfagel/www/rights.pdf .

16. Thomson J. The realm of rights. Cambridge, MA: Harvard University Press; 1990. pp. 122-124.

17. Beauchamp T, Childress J. Principles of biomedical ethics. $7^{\text {th }}$ edition. Oxford University Press; 2013. pp. 368-70.

18. Responding to pandemic influenza - the ethical framework for policy and planning. London: UK Department of Health, 2007. Available from: https://webarchive.nationalarchives.gov. uk/20130105020420/http://www.dh.gov.uk/prod_ consum_dh/groups/dh_digitalassets/@dh/@en/ documents/digitalasset/dh_080729.pdf.

19. Toner E, Waldhorn R. What US hospitals should do now to prepare for a COVID-19 pandemic. Baltimore: Johns Hopkins University Center for Health Security, 2020. Available from: http:// www.centerforhealthsecurity.org/cbn/2020/ cbnreport-02272020.html.

20. Influenza pandemic - providing critical care. North Sydney, Australia: Ministry of Health, NSW, 2010. Available from: https://www1.health.nsw.gov. au/pds/ActivePDSDocuments/PD2010_028.pdf.

21. World Health Organization, https://www.who. int/emergencies/diseases/novel-coronavirus-2019; (20.04.2020).

22. Taubenberger JK, Morens DM. 1918 Influenza: the mother of all pandemics. Emerg Infect Dis. 2006; 12(1):15-22. doi:10.3201/eid1201.050979. 